\title{
ANALISIS USAHA, NILAI TAMBAH, DAN KESEMPATAN KERJA AGROINDUSTRI TAHU DI BANDAR LAMPUNG
}

\author{
(Business Analysis, Added Value and Employment Opportunities of Tofu Agroindustry \\ in Bandar Lampung City)
}

Rosita, Agus Hudoyo, Achdiansyah Soelaiman

\begin{abstract}
Jurusan Agribisnis, Fakultas Pertanian, Universitas Lampung, J1. Prof. Dr. Soemantri Brojonegoro No. 1 Bandar Lampung 35145, Telp. 085928821707, e-mail: Rositasita67@yahoo.co.id
\end{abstract}

\begin{abstract}
The objectives of this study are to analize the business, the added-value and employment of the tofu agroindustry in Bandar Lampung. This study was conducted in Gunung Sulah and Kedamaian villages which are the tofu production centers. The respondents are randomly chosen. The data are processed by using the financial analysis and the value-added analysis. There are two kinds of tofu, i.e the kopong tofu dan the cina tofu. The average net revenues over the cash costs were Rp10.49 million/month of the kopong tofu and Rp12.10 million/month of the cina tofu. The average net revenues over the total costs were Rp4.02 million/month of the kopong tofu and Rp5.17 million/month of the cina tofu. The average standard costs were Rp16,949.97/kg of the kopong tofu and Rp9,206.70/kg of the cina tofu.The average added-value was Rp5,109.31/kg soybeans and its 95 percent confidence interval was Rp2,864.23-7,354.39/kg soybeans. The employment in the two tofu production centers was 143 people.
\end{abstract}

Key words: added value, agroindustry, business analysis, employment, tofu

\section{PENDAHULUAN}

Tahu merupakan salah satu makanan yang sering dikonsumsi masyarakat di Indonesia. Mutu protein suatu bahan pangan dapat dilihat dari kandungan asam amino penyusunnya. Kandungan asam amino tahu merupakan yang paling lengkap dari semua produk olahan kedelai. Selain sebagai sumber protein, tahu juga mengandung zat gizi lain yang diperlukan oleh tubuh seperti lemak, vitamin dan mineral.

Tahu mengandung air $86 \%$, protein $8-12 \%$, lemak $4-6 \%$, dan karbohidrat 1-6\%. Tahu juga mengandung berbagai mineral seperti kalsium, zat besi, fosfat, kalium, natrium, serta vitamin seperti kolin, vitamin B, dan vitamin E. Kandungan asam lemak jenuhnya rendah dan bebas kolesterol (Santoso 2005).

Berdasarkan BPS (2016) perkembangan konsumsi tahu secara berturut-turut tahun 2016-2017 yaitu sebesar 7,87 kg per kapita dan 7,88 kg per kapita per tahun. pada tahun 2017 dan terus meningkat menjadi sebesar 8,03 kg/kapita pada tahun 2019 . Konsumsi tahu yang terus meningkat serta jumlah penduduk yang terus meningkat berdampak pada permintaan tahu yang tinggi, sehingga usaha pengolahan tahu dapat dijadikan sebagai ladang bisnis.
Agroindustri tahu merupakan industri rumahan yang mengolah kacang kedelai dengan melalui berbagai proses produksinya hingga menghasilkan ouput berupa tahu. Agroindustri tahu dapat memberikan nilai tambah terhadap komoditas kedelai. Nilai tambah dapat memberikan pendapatan bagi agroindustri itu sendiri. Selain itu, nilai tambah juga dapat meningkatkan perekonomian masyarakat sekitar daerah tersebut. Selain itu, Berkembangnya agroindustri tahu dapat membuka kesempatan kerja bagi masyarakat di sekitar agroindustri tahu tersebut.

Industri tahu dalam menjalankan usahanya perlu mengetahui biaya pokok yang dikeluarkan selama proses produksi agar agroindustri tahu dapat menentukan harga jual tahu sesuai dengan biaya yang dikeluarkan, sehingga agroindustri tahu dapat memperhitungkan keuntungan yang diperoleh serta dapat meminimalisir kerugian. Keberlanjutan agroindustri tahu juga dapat dilihat dari besarnya biaya pokok yang dikeluarkan.

Penelitian mengenai analisis pendapatan dan nilai tambah agroindustri tahu telah dilakukan oleh peneliti terdahulu yaitu Wijoyono et al. (2015). Penelitian mengenai biaya pokok industri tahu juga sudah dilakukan oleh peneliti terdahulu yaitu Cahyani et al. (2015). Penelitian mengenai 
kesempatan kerja industri tahu juga sudah dilakukan oleh peneliti terdahulu yaitu Ayu et al. (2013). Berdasarkan penelitian tersebut maka perlu dianalisis mengenai empat aspek pada agroindustri tahu yakni aspek pendapatan, aspek biaya pokok, aspek nilai tambah dan aspek kesempatan kerja.

Berdasarkan latar belakang tersebut maka penelitian ini bertujuan untuk menganalisis ratarata pendapatan, rata-rata biaya pokok, rata-rata nilai tambah, dan bagaimana kesempatan kerja yang diciptakan oleh agroindustri tahu di Bandar Lampung.

\section{METODE PENELITIAN}

Penelitian dilakukan di Kota Bandar Lampung, yaitu di Kelurahan Gunung Sulah dan Kelurahan Kedamaian.Pemilihan lokasi penelitian dilakukan secara sengaja (purposive). Pertimbangan dalam memilih lokasi penelitian adalah bahwa kelurahan tersebut merupakan sentra agroindustri tahu di Bandar Lampung. Waktu penelitian dilakukan pada bulan Desember 2017 hingga Maret 2018.

Sampel yang digunakan dalam penelitian ini sebanyak 50 agroindustri tahu di Bandar Lampung. Menurut Cohen (2007) semakin besar sampel dari besarnya populasi yang ada akan semakin baik, akan tetapi ada jumlah batas minimal yang harus diambil oleh peneliti yaitu sebanyak 30 sampel. Penentuan sampel menggunakan metode simple random sampling menggunakan merupakan sebuah teknik pengambilan anggota sampel dari populasi yang dilakukan secara acak tanpa memperhatikan strata yang ada dalam populasi tersebut.

Data yang digunakan adalah data primer dan data sekunder. Data primer didapatkan dari wawancara langsung dengan responden menggunakan kuisioner. Data sekunder diperoleh dari publikasi instansi-instansi yang berkaitan dengan penelitian. Metode pengumpulan data dalam penelitian ini dilakukan dengan cara observasi dan wawancara. Observasi dilakukan dengan mengamati langsung keadaan atau situasi di lapangan. Wawancara dilakukan dengan pengumpulan data langsung dari pemilik atau karyawan pengrajin keripik pisang dengan menggunakan daftar pertanyaan yang telah disiapkan sebelumnya.

Analisis data yang digunakan pada penelitian ini adalah analisis kualitatif dan kuantitatif. Analisis deskriptif kualitatif dipakai untuk mendapatkan gambaran kondisi usaha agroindustri tahu serta bagaimana proses pengolahan kedelai menjadi tahu. Analisis kuantitatif digunakan untuk melihat analisis usaha, nilai tambah dan kesempatan kerja. Analisis usaha agroindustri tahu dibagi menjadi dua yaitu analisis biaya dan analisis pendapatan.

\section{Analisis Biaya}

Biaya total merupakan penjumlahan antara biaya tunai dan biaya diperhitungkan. Biaya pokok atau biaya total rata-rata merupakan pembagian antara biaya total dengan output yang dihasilkan. Menurut Soekartawi (2000), biaya total dan biaya total rata-rata atau biaya pokok dapat dihitung dengan menggunakan rumus sebagai berikut:

$$
\mathrm{TC}=\mathrm{TFC}+\mathrm{TVC}
$$

Biaya pokok $=\frac{\mathrm{TC}}{\mathrm{Y}}$

Keterangan:

$\mathrm{TC}=$ Total cost

TFC $=$ Total fixed cost

TVC = Total variabel cost

$\mathrm{Y}=$ Output

$\Pi \quad=$ Pendapatan

\section{Analisis Pendapatan}

Analisis pendapatan merupakan analisis kuantitatif yang digunakan untuk melihat berapa besar keuntungan yang diperoleh usaha pengolahan kedelai menjadi tahu. Analisis pendapatan dihitung dengan cara mengurangi penerimaan total dengan biaya total. Setelah dilakukan analisis pendapatan, kemudian dilakukan analisis $\mathrm{R} / \mathrm{C}$ rasio. Analisis $\mathrm{R} / \mathrm{C}$ rasio merupakan perbandingan antara penerimaan total dengan biaya total. Secara sistematis perhitungan penerimaan, pendapatan, dan $\mathrm{R} / \mathrm{C}$ ratio dapat dilihat sebagai berikut:

Menurut Debertin (2012), pendapatan pengelola dapat dihitung dengan menggunakan rumus sebagai berikut:

$\Pi$ pengelola $=\frac{\mathrm{TR}-\mathrm{TC}}{\sum \text { pengelola }}$

Menurut Soekartawi (2000), pendapatan dan R/C ratio dapat dihitung dengan menggunakan rumus sebagai berikut:

Pendapatan $=$ TR - TC 
$\mathrm{R} / \mathrm{C}$ atas biaya total $=\frac{\Pi}{\mathrm{TC}}$

$\mathrm{R} / \mathrm{C}$ atas biaya tunai $=\frac{\Pi}{\mathrm{TVC}}$

Jika R/C >1, maka suatu usaha mengalami keuntungan, karena penerimaan lebih besar dari biaya, sedangkan jika $\mathrm{R} / \mathrm{C}<1$, maka suatu usaha mengalami kerugian, karena penerimaan lebih kecil dari biaya. Jika $\mathrm{R} / \mathrm{C}=1$, maka suatu usaha mengalami impas, karena penerimaan sama dengan biaya.

\section{Analisis Nilai Tambah}

Menurut Hayami (1987), analisis nilai tambah pengolahan produk pertanian dapat dilakukan dengan cara sederhana, yaitu melalui perhitungan nilai tambah per kilogram bahan baku untuk satu kali pengolahan yang menghasilkan produk tertentu. Analisis nilai tambah dilakukan untuk mengetahui besarnya nilai tambah dari pengolahan kedelai menjadi tahu selama proses produksi.

Perhitungan nilai tambah menurut Hayami (1987) dapat dirumuskan sebagai berikut:

$\begin{aligned} \text { Nilai Tambah }= & \text { Nilai output }- \text { Harga bahan } \\ & \text { baku-Sumbangan input lain }- \\ & \text { Imbalan tenaga kerja .............(7) }\end{aligned}$

Dengan kriteria penilaian sebagai berikut.

a. Jika NT >0, artinya agroindustri tahu memberikan nilai tambah (positif).

b. Jika NT $<0$, artinya agroindustri tahu tidak memberikan nilai tambah (negatif).

\section{HASIL DAN PEMBAHASAN}

\section{Karakteristik Responden Pengrajin Tahu}

Berdasarkan hasil penelitian umur responden sangat bervariasi mulai dari umur 28 tahun sampai umur 68 tahun. Sebagian besar tingkat pendidikan pengrajin tahu di Bandar Lampung adalah tamatan sekolah dasar. Jumlah tanggungan pengrajin tahu di daerah penelitian berkisar antara 3-4 orang. Pengalaman usaha responden berkisar antara 1-40 tahun.

Responden pada penelitian ini sebanyak 50 pengrajin tahu yang terdiri dari pria dan wanita, sebagian besar responden pada penelitian ini berjenis kelamin pria yaitu sebanyak 43 orang sedangkan responden wanita sebanyak tujuh orang. Pada penelitian ini ada dua jenis tahu yang diteliti yaitu tahu kopong dan tahu cina.

\section{Penyediaan Bahan Baku Utama dan Bahan Baku Penunjang}

Bahan baku utama dalam proses pengolahan tahu cina dan tahu kopong adalah kacang kedelai impor. Pengrajin tahu lebih memilih menggunakan kacang kedelai impor karena mutunya jauh lebih bagus dan selalu tersedia dibandingkan dengan kacang kedelai lokal. Dalam proses pembuatan tahu diperlukan juga bahan penolong yaitu obat tahu atau sering disebut sakau, garam, air, kayu bakar, plastik, dan minyak goreng.

Rata-rata biaya bahan baku utama yang dikeluarkan oleh pengrajin tahu baik tahu kopong maupun tahu cina selama satu bulan yaitu sebesar Rp11.175.000,00. Penggunaan bahan penunjang dalam satu bulan produksi untuk pembuatan tahu kopong yaitu sebesar Rp6.905.697,61 dan untuk tahu cina sebesar Rp4.569.472,44. Biaya sumbangan input lain untuk pembuatan tahu kopong yaitu sebesar Rp7.555.220,32 dan untuk tahu cina sebesar Rp5.197.46,23.

Proses pembuatan untuk tahu kopong membutuhkan minyak goreng sedangkan dalam proses pembuatan tahu cina tidak menggunakan minyak goreng sehingga biaya bahan penunjang dan sumbangan input lain tahu kopong lebih besar dari tahu cina. Bahan baku utama dan bahan baku penolong yang digunakan dalam proses pembuatan tahu dalam satu bulan dijelaskan pada Tabel 1 .

\section{Penggunaan Peralatan}

Sebagian besar pengrajin tahu menggunakan modal sendiri dalam menjalankan usahanya. Modal investasi pengrajin tahu berupa peralatan yang digunakan dalam proses produksi tahu. Peralatan yang digunakan oleh pengrajin tahu umumnya masih sederhana. Peralatan yang digunakan oleh pengrajin tahu kopong dan tahu cina sedikit berbeda.

Pengrajin tahu kopong tidak menggunakan drum alumunium sedangkan pengrajin tahu cina menggunakan drum alumunium. Pengrajin tahu kopong menggunakan papan cetakan dalam mencetak tahu kopong sedangkan pengrajin tahu cina menggunakan kain saring yang sudah dipotong-potong untuk mencetak tahu cina. 
Tabel 1. Bahan baku utama dan bahan baku penunjang yang digunakan dalam pembuatan tahu selama satu bulan per $50 \mathrm{~kg}$ kedelai tahun 2018

\begin{tabular}{|c|c|c|c|}
\hline \multirow{2}{*}{ No } & \multirow{2}{*}{ Uraian } & \multicolumn{2}{|c|}{ Biaya (Rp/bln) } \\
\hline & & Tahu Kopong & Tahu Cina \\
\hline \multicolumn{4}{|c|}{ Bahan baku utama } \\
\hline & Kedelai & $11.175 .000,00$ & $11.175 .000,00$ \\
\hline Tota & al bahan baku utama & $11.175 .000,00$ & $11.175 .000,00$ \\
\hline \multicolumn{4}{|c|}{ Bahan baku penunjang } \\
\hline & Garam & $288.511,90$ & $270.679,95$ \\
\hline & $\begin{array}{l}\text { Plastik } \\
\text { pembungkus }\end{array}$ & $1.024 .411,90$ & $626.026,92$ \\
\hline & Kayu Baka & $3.290 .773,81$ & $3.352 .930,40$ \\
\hline & Miny & $2.302 .000,00$ & 0,00 \\
\hline & Sakau & 0 & $113.950,55$ \\
\hline & Karet pembungkus & 0 & $205.884,62$ \\
\hline \multicolumn{2}{|c|}{$\begin{array}{l}\text { Total bahan baku } \\
\text { penunjang }\end{array}$} & $6.905 .697,61$ & $4.569 .472,44$ \\
\hline Sum & bangan Input lain & $7.555 .220,32$ & $5.197 .461,23$ \\
\hline
\end{tabular}

Penyusutan peralatan mesin giling merupakan penyusutan peralatan paling besar dalam agroindustri tahu yaitu sebesar Rp 43.783,07/bulan untuk mesin giling tahu kopong dan $\mathrm{Rp}$ $38.787,01 /$ bulan untuk mesin giling tahu cina. Total penyusutan peralatan agroindustri tahu kopong yaitu sebesar Rp135.861,03/bulan dan Rp112.852,36/bulan untuk tahu cina. Secara rinci penyusutan peralatan yang digunakan dalam proses pengolahan tahu dapat dilihat pada Tabel 2.

Peralatan yang digunakan dalam proses pembuatan tahu kopong lebih banyak dibandingkan dengan tahu cina, hal ini dikarenakan proses pengolahan tahu kopong lebih panjang dibandingkan dengan proses pengolahan tahu cina. Dalam proses pengolahan tahu kopong, tahu yang sudah dicetak digoreng terlebih dahulu sedangkan untuk tahu cina setelah dicetak dapat langsung dipasarkan.

\section{Penggunaan Tenaga Kerja}

Dalam industri pembuatan tahu diperlukan tenaga kerja untuk mengerjakan berbagai kegiatan produksi seperti perendaman, penggilingan, penyaringan, perebusan, penggorengan sampai pemasaran. Sebagian besar tenaga kerja yang digunakan dalam proses pengolahan tahu di daerah penelitian yaitu tenaga kerja dalam keluarga yang terdiri dari suami dan istri tetapi ada juga yang menggunakan tenaga kerja luar keluarga.

Pengrajin tahu kopong menggunakan tenaga kerja luar keluarga juga tetapi tidak dilibatkan dalam semua kegiatan produksi hanya kegiatan penggorengan tahu kopong saja. Sedangkan untuk pengrajin tahu cina ada beberapa yang menggunakan tenaga kerja luar keluarga untuk semua kegiatan produksi tahu. Rata-rata penggunaan tenaga kerja pria dan wanita dalam pembuatan tahu kopong untuk satu kali produksi adalah sebesar 0,74 HOK untuk pria dan 1,04 HOK untuk wanita. Penggunaan tenaga kerja pria dan wanita dalam proses pembuatan tahu cina untuk satu kali produksi yaitu sebesar $0,45 \mathrm{HOK}$ untuk pria dan 1,08 HOK untuk wanita. Penggunaan tenaga kerja pada usaha industri tahu dapat dilihat pada Tabel 3.

Jumlah penggunaan tenaga kerja wanita baik untuk tahu kopong dan tahu cina lebih besar dibandingkan dengan penggunaan tenaga kerja pria, hal ini dikarenakan dalam proses pembuatan tahu kopong dan tahu cina tenaga kerja wanita dibutuhkan pada proses kegiatan penggorengan, pencetakkan tahu untuk tahu cina serta distribusi yang membutuhkan waktu yang cukup lama.

Tabel 2. Penyusutan peralatan industri tahu kopong dan tahu cina tahun 2018

\begin{tabular}{clrr}
\hline \multirow{2}{*}{ No } & \multirow{2}{*}{ Nama Alat } & \multicolumn{2}{c}{ Penyusutan (Rp/bulan) } \\
\cline { 3 - 4 } & & Tahu Kopong & \multicolumn{1}{c}{ Tahu Cina } \\
\hline 1. & Drum kaleng & $4.652,28$ & 0,00 \\
2. & Drum plastik & $3.872,09$ & 0,00 \\
3. & Papan cetakan & $13.277,78$ & $19.089,85$ \\
4. & Mesin giling & $43.783,07$ & $38.787,01$ \\
5. & Tungku & $9.359,46$ & $5.763,02$ \\
6. & Ember & $5.245,70$ & $2.461,80$ \\
7. & Kain Saring & $7.562,50$ & $15.682,43$ \\
8. & Rak & 367,39 & 0,00 \\
9. & Kerek & $18.077,38$ & 0,00 \\
10. & Gayung & 962,96 & 884,65 \\
11. & Pisau & 407,76 & 0,00 \\
12. & Kuali & $12.356,15$ & 0,00 \\
13. & Spatula & $3.355,82$ & 0,00 \\
14. & Mesin sanyo & $12.580,69$ & $15.689,93$ \\
& Drum & & \\
15. & Allumunium & & \\
& Besar & 0,00 & $8.454,64$ \\
& Kecil & 0,00 & $6.039,03$ \\
\hline & Total & $135.861,03$ & $112.852,36$ \\
\hline
\end{tabular}

Tabel 3. Penggunaan tenaga kerja agroindustri tahu kopong dan tahu cina (HOK)

\begin{tabular}{clccccc}
\hline \multirow{2}{*}{ No } & \multirow{2}{*}{ Kegiatan } & \multicolumn{2}{c}{ Tahu kopong } & \multicolumn{2}{c}{ Tahu cina } & \multirow{2}{*}{ Total } \\
\cline { 3 - 6 } & & $\mathrm{P}$ & $\mathrm{W}$ & $\mathrm{P}$ & $\mathrm{W}$ & \\
\hline 1. & $\begin{array}{l}\text { Perendaman } \\
\text { \& Pencucian }\end{array}$ & 0,14 & 0,00 & 0,10 & 0,00 & 0,24 \\
2. & Penggilingan & 0,15 & 0,00 & 0,15 & 0,00 & 0,30 \\
3. & Pemerasan & 0 & 0,00 & 0,10 & 0,00 & 0,10 \\
4. & Perebusan & 0,14 & 0,00 & 0,10 & 0,00 & 0,24 \\
5. & Penyaringan & 0,14 & 0,00 & 0,00 & 0,00 & 0,14 \\
6. & Pencetakan \& & 0,17 & 0,00 & 0,00 & 0,42 & 0,59 \\
& pemotongan & & & & & \\
7. & Penggorengan & 0,00 & 0,30 & 0,00 & 0,00 & 0,30 \\
8. & Distribusi & 0,00 & 0,74 & 0,00 & 0,66 & 1,40 \\
\hline & Total & 0,74 & 1,04 & 0,45 & 1,08 & 3,31 \\
\hline
\end{tabular}


Industri tahu kopong dan tahu cina yang menggunakan sumber tenaga kerja luar keluarga dapat dipenuhi dari penduduk yang bertempat tinggal disekitar lokasi usaha. Dengan demikian, dapat dikatakan bahwa ketersediaan tenaga kerja didaerah penelitian cukup tersedia.

\section{Proses Produksi}

Dari hasil pengamatan dan wawancara dengan responden di daerah penelitian terdapat dua jenis tahu yang diteliti yaitu tahu kopong dan tahu cina. Proses pembuatan tahu kopong terdiri dari perendeman kedelai, penggilingan kedelai, perebusan bubur kedelai, penyaringan bubur kedelai, pencetakkan dan pemotongan tahu, penggorengan tahu kopong, serta pemasaran tahu. Sedangkan proses pengolahan tahu cina terdiri dari perendaman kedelai, penggilingan kedelai, pemerasan bubur kedelai, perebusan bubur kedelai, pencetakkan tahu, dan pemasaran tahu.

\section{Analisis Pendapatan}

Pendapatan diperoleh dari selisih antara penerimaan dan biaya total selama sebulan. Pendapatan diatas biaya tunai dan pendapatan diatas biaya total merupakan selisih antara penerimaan dengan biaya total. Pendapatan pengelola merupakan pendapatan pengelola yang diterima setiap bulannya. $\mathrm{R} / \mathrm{C}$ merupakan perbandingan antara penerimaan dengan biaya, baik biaya tunai maupun biaya total.

Penerimaan yang diperoleh rata-rata industri tahu selama satu bulan yaitu sebesar Rp29.858.810,00 untuk tahu kopong dan sebesar Rp29.993.736,26 untuk tahu cina. Pendapatan atas biaya tunai yang diperoleh pengrajin tahu yaitu sebesar Rp10.498.254,76 untuk tahu kopong dan Rp12.105.022,53 untuk tahu cina. Pendapatan atas biaya total yang diperoleh pengrajin tahu yaitu sebesar Rp4.579.716,02 untuk tahu kopong dan Rp6.980.752,83 untuk tahu cina. Secara rinci penerimaan dan pendapatan industri pengolahan tahu kopong dan tahu cina dapat dilihat pada Tabel 4.

Pendapatan lainnya yaitu pendapatan yang diperoleh pengrajin tahu kopong dari hasil mengontrakan atau menjual ampas tahunya. Pendapatan lainnya yang diperoleh rata-rata pengrajin tahu kopong dan tahu cina selama satu bulan yaitu sebesar Rp170.833,33 dan Rp190.416,67. Pendapatan pengelola agroindustri tahu kopong dan tahu cina yaitu sebesar Rp5.249.127,38 untuk kopong dan Rp6.052.51,26 untuk tahu cina.

Agroindustri tahu kopong dan tahu cina menguntungkan karena nilai $\mathrm{R} / \mathrm{C}>1$. Hal tersebut menunjukkan bahwa hasil penelitian ini sejalan dengan penelitian Anggraeni, Lestari dan Indriyani (2017) yang menunjukkan bahwa rata-rata pendapatan usaha tempe selama sebulan yaitu Rp5.132.926,90 dengan jumlah produksi sebesar $1.651 \mathrm{~kg} / \mathrm{bulan}$ serta usaha tersebut menguntungkan karena nilai $\mathrm{R} / \mathrm{C}>1$.

\section{Analisis Biaya Pokok}

Biaya pokok pengrajin tahu merupakan semua biaya yang dikeluarkan oleh pengrajin tahu untuk menjalankan proses produksi. Biaya pokok industri pengolahan tahu diperoleh dari perbandingan total biaya yang dikeluarkan dengan output yang dihasilkan.

Biaya total yang dikeluarkan oleh pengrajin tahu kopong adalah sebesar Rp25.279.09,50 dan untuk tahu cina adalah sebesar Rp23.012.98,43. Rata-rata biaya tunai merupakan biaya tunai yang dikeluarkan per satu kilogram output. Biaya tunai rata-rata yang dikeluarkan pengrajin tahu yaitu sebesar Rp12.968,05 untuk tahu kopong dan Rp7.148,98 untuk tahu cina.

Tabel 4. Perhitungan pendapatan industri tahu kopong dan tahu cina di Bandar Lampung selama satu bulan per $50 \mathrm{~kg}$ kedelai

\begin{tabular}{rlrr}
\hline No & \multicolumn{1}{c}{ Uraian } & Tahu Kopong & \multicolumn{1}{c}{ Tahu Cina } \\
\hline A. & Biaya total & $25.279 .093,50$ & $22.012 .983,43$ \\
B. & $\begin{array}{l}\text { Penerimaan } \\
\text { produksi }(\mathrm{kg})\end{array}$ & $1.492,94$ & $2.499,56$ \\
& $\begin{array}{l}\text { Harga }(\mathrm{Rp} / \mathrm{kg}) \\
\text { Total penerimaan } \\
\text { (Rp/kg) }\end{array}$ & $29.000,00$ & $12.000,00$ \\
D. & $\begin{array}{l}\text { Pendapatan diatas } \\
\text { biaya tunai }\end{array}$ & $10.498 .254,76$ & $12.105 .022,53$ \\
E. & $\begin{array}{l}\text { Pendapatan diatas } \\
\text { biaya total }\end{array}$ & $4.579 .716,02$ & $6.980 .752,83$ \\
F. & $\begin{array}{l}\text { Pendapatan } \\
\text { lainnya }\end{array}$ & $170.833,33$ & $190.416,67$ \\
G. & $\begin{array}{l}\text { Pendapatan } \\
\text { pengelola }\end{array}$ & $5.249 .127,38$ & $6.052 .511,26$ \\
H. & $\begin{array}{l}\text { R/C Ratio atas } \\
\text { biaya tunai }\end{array}$ & 1,54 & 1,68 \\
I. & $\begin{array}{l}\text { R/C Ratio atas } \\
\text { biaya total }\end{array}$ & 1,18 & 1,3 \\
\hline
\end{tabular}


Biaya pokok yang dikeluarkan oleh pengrajin tahu untuk produksi tahu kopong adalah sebesar Rp16.949,97/kg dengan harga jual sebesar Rp20.000 serta untuk tahu cina adalah sebesar Rp9.206,70/kg dengan harga jual sebesar Rp12.000.

Berdasarkan hasil penelitian rata-rata harga jual yang ditentukan oleh pengrajin tahu sudah diatas biaya pokok yang dikeluarkan sehingga pengrajin tahu sudah memperoleh keuntungan. Hal tersebut menunjukkan bahwa hasil penelitian ini sejalan dengan penelitian Agustina, Ismono dan Nugraha (2015) yang menunjukkan bahwa agroindustri marning memperoleh keuntungan dengan harga pokok produksi yaitu sebesar Rp9.809,55 dan harga jual sebesar Rp12.000.

Biaya pokok juga dihitung menggunakan selang kepercayaan sehingga nilai dari biaya pokok pengrajin tahu tidak hanya terfokus pada satu titik nilai saja. Biaya pokok pengrajin tahu kopong berada pada selang kepercayaan sebesar Rp15.261,74- Rp18.638,21/kg. Sedangkan biaya pokok pengrajin tahu cina berada pada selang kepercayaan sebesar Rp7.407,54- Rp9.586,37. Secara rinci total biaya produksi agroindustri tahu kopong dan tahu cina dapat dilihat pada Tabel 5.

\section{Analisis Nilai Tambah}

Nilai tambah yang diukur adalah nilai tambah yang dihasilkan dari pengolahan kacang kedelai menjadi tahu. Nilai tambah diperoleh dari hasil pengurangan antara nilai output dengan harga bahan baku dan sumbangan input lain. Nilai tambah tersebut merupakan nilai tambah kotor karena belum dikurangi dengan imbalan tenaga kerja.

Tabel 5. Total biaya produksi agroindustri tahu kopong dan tahu cina (per $50 \mathrm{~kg}$ ) selama satu bulan

\begin{tabular}{|c|c|c|c|}
\hline No & Uraian & Tahu Kopong & Tahu Cina \\
\hline 1. & Total Biaya tunai & $19.360 .554,76$ & $17.888 .713,74$ \\
\hline 2. & $\begin{array}{l}\text { Total Biaya } \\
\text { diperhitungkan }\end{array}$ & $5.918 .538,74$ & $5.124 .269,69$ \\
\hline 3. & Total Biaya & $25.279 .093,50$ & $23.012 .983,43$ \\
\hline 4. & $\begin{array}{l}\text { Rata-rata biaya } \\
\text { tunai }(\mathrm{Rp} / \mathrm{kg})\end{array}$ & $12.968,05$ & $7.148,98$ \\
\hline 5. & $\begin{array}{l}\text { Biaya Pokok } \\
(\mathrm{Rp} / \mathrm{kg})\end{array}$ & $16.949,97$ & $9.206,70$ \\
\hline 6. & $\begin{array}{l}\text { Standar deviasi } \\
(\mathrm{Kg})\end{array}$ & $1.688,24$ & $1.089,41$ \\
\hline \multirow[t]{3}{*}{7.} & Selang Kepercayaa & Biaya Pokok (kg) & \\
\hline & Batas bawah & $15.261,74$ & $7.407,54$ \\
\hline & Batas atas & $18.638,21$ & $9.586,37$ \\
\hline
\end{tabular}

Pada penelitian ini nilai tambah yang dihitung adalah nilai tambah bersih sehingga nilai tambah dihitung dengan cara pengurangan antara nilai output dikurangi harga bahan baku dikurangi sumbangan input lain dan dikurangi dengan imbalan tenaga kerja.

Nilai tambah yang diperoleh pengrajin tahu kopong adalah sebesar Rp4.521,94 dan nilai tambah tahu cina yaitu sebesar Rp5.990,47. Nilai tambah untuk tahu merupakan nilai tambah gabungan dari tahu kopong dan tahu cina sehingga diperoleh nilai tambah pengrajin tahu di Kota Bandar Lampung yaitu sebesar Rp5.109,3.

Nilai tambah yang dihasilkan dari industri tahu baik tahu kopong maupun tahu cina memberikan nilai tambah (positif). Hal tersebut menunjukkan bahwa hasil penelitian ini sejalan dengan penelitian Arum, Widjaya dan Marlina (2015) hasil penelitian menunjukkan bahwa usaha agroindustri tempe memberikan nilai tambah lebih besar daripada nol $(\mathrm{NT}>0)$. Secara rinci perhitungan nilai tambah tahu kopong dan tahu cina dapat dilihat pada Tabel 6.

Pada penelitian ini nilai tambah dihitung menggunakan selang kepercayaan (95\%) sehingga nilai dari nilai tambah berada pada dua titik. Nilai tambah dari tahu kopong berada pada selang kepercayaan Rp2.731,47-Rp6.312,42. Sedangkan nilai tambah dari tahu cina berada pada selang kepercayaan Rp4.257,05-Rp7.72,69. Nilai tambah tahu berada pada selang kepercayaan Rp2.864,23Rp7.354,39.

Tabel 6. Nilai tambah tahu kopong dan tahu cina di Bandar Lampung

\begin{tabular}{|c|c|c|c|c|}
\hline \multirow[b]{2}{*}{ No } & \multirow[b]{2}{*}{ Uraian } & \multicolumn{3}{|c|}{ Nilai } \\
\hline & & $\begin{array}{c}\text { Tahu } \\
\text { Kopong }\end{array}$ & Tahu Cina & Tahu \\
\hline 1. & $\begin{array}{l}\text { Nilai output } \\
\text { (Rp/kg) }\end{array}$ & $19.905,97$ & $19.995,82$ & $19.941,85$ \\
\hline 2. & $\begin{array}{l}\text { Harga Bahan } \\
\text { Baku (Rp/kg) }\end{array}$ & $7.453,00$ & $7.450,00$ & $7.450,00$ \\
\hline 3. & $\begin{array}{l}\text { Sumbangan } \\
\text { Input Lain } \\
\text { (Rp/kg) }\end{array}$ & $5.088,81$ & $3.464,97$ & $4.408,08$ \\
\hline 4. & $\begin{array}{l}\text { Imbalan Tenaga } \\
\text { Kerja }\end{array}$ & $2.897,12$ & $3.090,48$ & $2.974,46$ \\
\hline 5. & Nilai Tambah & $4.521,94$ & $5.990,37$ & $5.109,31$ \\
\hline 6. & $\begin{array}{l}\text { Rasio Nilai } \\
\text { Tambah }(\%)\end{array}$ & 37,00 & 45,00 & 40,00 \\
\hline $\begin{array}{l}7 . \\
8 .\end{array}$ & $\begin{array}{l}\text { Standar deviasi } \\
\text { Selang } \\
\text { kepercayaan }\end{array}$ & $1.790,05$ & $1.733,32$ & $2.245,08$ \\
\hline & Batas Bawah & $2.731,47$ & $4.257,05$ & $2.864,23$ \\
\hline & Batas Atas & $6.312,42$ & $7.723,69$ & $7.354,39$ \\
\hline
\end{tabular}


Menurut Sudoyo (2004) rasio nilai tambah menunjukkan persentase nilai tambah dari nilai output, artinya jika rasio nilai tambah $>50 \%$ maka nilai tambah lebih besar dari pada nilai output dan nilai tambah tergolong tinggi, sedangkan jika rasio nilai tambah $\leq 50 \%$, maka nilai tambah yang dihasilkan lebih kecil dari nilai outputnya dan nilai tambah tergolong rendah.

Rasio nilai tambah tahu kopong yang diperoleh dari perhitungan adalah sebesar $37 \%$ dan rasio nilai tambah untuk tahu kopong sebesar $45 \%$, serta rasio nilai tambah tahu yaitu sebesar $40 \%$. Hal tersebut menunjukan bahwa nilai tambah yang dihasilkan dari usaha pengolahan tahu kopong dan tahu cina masih tergolong rendah.

Hasil penelitian Anggraeni, Lestari dan Indriyani (2017) menunjukkan bahwa rasio nilai tambah agroindustri tempe yang dihasilkan yaitu sebesar $30,02 \%$, sedangkan pada penelitian ini rasio nilai tambah yang dihasilkan yaitu sebesar $40 \%$, hal tersebut menunjukkan bahwa rasio nilai tambah pada penelitian ini lebih besar bila dibandingkan dengan penelitian terdahulu.

Berdasarkan BPS (2017) dalam PDRB menurut lapangan usaha Kota Bandar Lampung atas dasar harga berlaku terdapat 17 kategori lapangan usaha dan sebagian besar kategori dirinci lagi menjadi sub kategori. Industri pengolahan merupakan salah satu penyumbang PDRB di Kota Bandar Lampung. Industri pengolahan di Kota Bandar Lampung menyumbang PDRB sebesar Rp10.815.114,50.

Berdasarkan BPS (2017) Konsumsi tahu per kapita selama setahun di Kota Bandar Lampung yaitu sebesar 8,164,00 $\mathrm{kg}$ dengan jumlah penduduk sebanyak 1.015.910,00 jiwa, sehingga konsumsi tahu per kapita selama setahun yaitu sebesar 8.293.889,00 kg/tahun. Kebutuhan kedelai untuk konsumsi tahu selama setahun yaitu sebesar 10.677.969,00 kg/tahun. Kontribusi industri pengolahan tahu terhadap PDRB diperoleh dengan cara mengalikan nilai tambah total tahu dengan kebutuhan kedelai untuk konsumsi tahu selama setahun, sehingga diperoleh kontribusi industri pengolahan terhadap PDRB di Kota Bandar Lampung sebesar 54.553.741.687,00 dengan presentase sebesar $0,50 \%$.

\section{Analisis Kesempatan Kerja}

Tenaga kerja merupakan penggerak semua kegiatan dalam usaha pengolahan tahu. Kesempatan kerja merupakan sebuah peluang untuk bekerja pada lapangan pekerjaan yang tercipta dari kegiatan usaha pengolahan tahu. Kesempatan kerja yang tercipta di sekitar wilayah industri pengolahan tahu sangat dipengaruhi oleh jumlah produksi atau jumlah bahan baku yang diproduksi, karena semakin banyak jumlah bahan baku yang diproduksi maka industri pengolahan tahu akan lebih banyak membutuhkan tenaga kerja.

Berdasarkan Tabel 7 total jumlah tenaga kerja pria dan wanita untuk pembuatan tahu kopong yaitu sebanyak 30 orang pria dan 41 orang wanita. Jumlah tenaga kerja pria untuk pembuatan tahu cina yaitu sebanyak 26 orang dan tenaga kerja wanita sebanyak 26 orang. Total jumlah tenaga kerja pria dan wanita baik tahu kopong maupun tahu cina yaitu sebanyak 71 orang untuk tahu kopong dan 52 orang untuk tahu cina, sehingga tenaga kerja yang terserap di sentra industri pengolahan tahu baik tahu kopong maupun tahu cina yaitu sebanyak 143 orang.

Tenaga kerja pria dalam pengolahan tahu bekerja pada kegiatan perendaman dan pencucian kedelai, penggilingan kedelai, pemerasan dan penyaringan, perebusan serta pencetakkan dan pemotongan tahu. Sedangkan tenaga kerja wanita pada industri tahu kopong bekerja pada kegiatan penggorengan dan untuk industri tahu cina bekerja pada kegiatan pencetakkan dan pemotongan tahu cina. Secara rinci jumlah orang yang bekerja di industri tahu di daerah penelitian dapat dilihat pada Tabel 7 .

Berdasarkan BPS (2017) jumlah penduduk berumur 15 tahun keatas yang bekerja selama seminggu yang lalu menurut lapangan pekerjaan utama dan jenis kelamin di Kota Bandar Lampung terdapat 9 lapangan pekerjaan utama, salah satunya yaitu lapangan pekerjaan di bidang industri pengolahan. Total jumlah penduduk berumur 15 tahun keatas yang bekerja di bidang industri pengolahan yaitu sebanyak 42.921 jiwa. Kontribusi penyerapan tenaga kerja agroindustri tahu di daerah penelitian yaitu sebesar $0,33 \%$ dari total jumlah penduduk berumur 15 tahun ke atas yang bekerja di industri pengolahan di Kota Bandar Lampung.

Tabel 7. Kesempatan kerja di sentra industri tahu kopong dan tahu cina di Bandar Lampung

\begin{tabular}{lccc}
\hline \multirow{2}{*}{$\begin{array}{c}\text { Jenis tenaga } \\
\text { kerja }\end{array}$} & \multicolumn{2}{c}{ Jumlah tenaga kerja (orang) } & \multirow{2}{*}{ Total } \\
\cline { 2 - 3 } & Gunung Sulah & Kedamaian & \\
\hline Pria & 30 & 26 & 56 \\
Wanita & 41 & 26 & 87 \\
\hline Total & 71 & 52 & 143 \\
\hline
\end{tabular}




\section{KESIMPULAN}

Rata-rata pendapatan di atas biaya total yaitu sebesar Rp4,02 juta/bulan untuk tahu kopong dan Rp5,17 juta/bulan untuk tahu cina. Rata-rata pendapatan di atas biaya tunai yaitu sebesar Rp4,02 juta/bulan untuk tahu kopong dan Rp5,17 juta/bulan untuk tahu cina. Rata-rata biaya pokok yaitu sebesar Rp16.949,97/kg untuk tahu kopong dan Rp9.206,70/kg untuk tahu cina. Rata-rata nilai tambah yaitu sebesar Rp5.109,31/kg kedelai dan selang kepercayaannya (95\%) yaitu sebesar Rp2.864,23-Rp7.354,39/kg kedelai. Industri tahu dapat menyerap tenaga kerja sebanyak 143 orang.

\section{DAFTAR PUSTAKA}

Agustina RD, Ismono HR dan Nugraha A. 2015. Harga pokok produksi, nilai tambah, dan prospek pengembangan agroindustri marning di kecamatan gedong tataan kabupaten pesawaran. JIIA, 3 (2) : 157-164. http:// jurnal.fp.unila.ac.id/index.php/JIA/article/vie w/1034/939. [12 Februari 2019].

Anggraeni TS, Lestari DAH dan Indriyani Y. 2017. Keragaan agroindustri tempe anggota Primkopti Kabupaten Pesawaran. JIIA, 5 (3): 275-282. http://jurnal.fp.unila.ac.id/ index.php /JIA/article/view1640/1466. [12 Februari 2019].

Arum PW, Widjaya S, dan Marlina L. 2017. Kelayakan usaha dan nilai tambah agroindustri tempe. JIIA, 5 (2) : 124-133. http://jurnal.fp.unila.ac.id/index.php/JIA/articl e/view/1649/1475. [12 Februari 2019].

Ayu BW. 2013. Analisis Pendapatan, Nilai Tambah, dan Kesempatan Kerja Pada Klaster Industri Pengolahan Ikan Teri Kering Di Pulau Pasaran Kota Bandar Lampung. Skripsi.
Fakultas Pertanian. Universitas Lampung. Bandar Lampung.

Badan Pusat Statistik. 2016. Survei Sosial Ekonomi Nasional (Susenas) Tahun 2016. Badan Penelitian dan Pengembangan Kesehatan. Jakarta.

BPS [Badan Pusat Statistik]. 2017. Survei Sosial Ekonomi Nasional (Susenas) . Badan Pusat Statistik. Jakarta.

BPS [Badan Pusat Statistik]. 2017. Lampung Dalam Angka. Badan Pusat Statistik Provinsi Lampung. Bandar Lampung.

Cahyani GFN. 2015. Analisis Perhitungan Harga Pokok Produksi pada Pabrik Tahu Sari Langgeng Kutoarjo. Skripsi. Fakultas Ekonomi. Universitas PGRI Yogyakarta. Yogyakarta.

Cohen L, Manion L, dan Morrison K. 2007. Research Methods in Education. Sixth Edition. New York.

Debertin DL. 2012. Agricultural Production Economics. Second Edition. University of Kentucky. Uknowledge.

Hayami Y, Toshihiko K, Yhosinori M, dan Masdjidin S. 1987. Agricultural Marketing and Processing In Upland Java: A Prospectif From A Sunda Village. Vilage The CGPRT . Bogor.

Soekartawi. 2000. Pengantar Agroindustri. Raja Grafindo Persada. Jakarta.

Santoso. 2005. Teknologi Pengolahan Kedelai (Teori Dan Praktek). Fakultas Pertanian Universitas Widyagama. Malang.

Wiyono T. 2015. Analisis pendapatan dan nilai tambah usaha tahu pada industri rumah tangga wajianto di Desa Ogurandu Kecamatan Bolano Lambunu Kabupaten Parigi Moutong. e-J. Agrotekbis 3 (3): 421-426. 